\title{
An Analysis of Occupational Accidents in Demolition Work
}

\author{
Hüseyin Ertaş", Ali Sayıl Erdoğan \\ Department of Civil Engineering, Firat University, Turkey
}

Copyright $\bigcirc 2017$ by authors, all rights reserved. Authors agree that this article remains permanently open access under the terms of the Creative Commons Attribution License 4.0 International License

\begin{abstract}
The significance of occupational health and safety is becoming better understood every day, and in this respect, countries institute various arrangements and conditions. Measures to be taken to prevent occupational accidents and disease are determined, and laws and regulations are made accordingly. Thousands of accidents happen every year in the construction sector, which is one of the most dangerous in terms of safety. These range from simple cuts and scratches to life changing injuries and death. It is also important to consider demolition work, which is one of the branches of the construction sector and a permanent part of our daily life, according to occupational health and safety. In this article, demolition work is discussed according to occupational health and safety statistics and occupational accidents in demolition are considered. The accidents studied and classified are taken from all 653 occupational accidents in demolition work registered in 1984-2012 in the workers' section of the US Occupational Safety and Health Administration (OSHA). According to the analyzed records, each kind of hazard in demolition work is evaluated with regard to different work procedures and the results are shown.
\end{abstract}

Keywords Occupational Accidents, Demolition Work, Accident Analysis, Occupational Accidents in Demolition Work

\section{Introduction}

Today, demolition work has become an indicator of the economic activity of countries. The presence of demolition work is considered as a sign of progress, improvement and growth [1]. Several urban transformation projects are applied in different cities of countries due to various needs of growth [2-6]. Urban transformation projects also accelerate the demolition work. Many of the dangers of demolition and construction work are common but demolition work also has its own hazards. The substances in the composition of the materials demolished or removed (lead paint, the presence of asbestos etc.) and areas with sharp edges or protruding spikes are examples of these hazards. Moreover, accidents caused by structural collapse and broken glass resulting from damage done to the building during demolition also happen frequently. Demolition work is often small-scale and it is a sector in which contractors are self-employed and many workers are unqualified [7]. In addition, if non-professional demolition companies are not inspected according to occupational health and safety regulations, the likelihood of accidents could increase.

Demolition work is the type of job that is always expected to be faster and cheaper than general construction work. In the project management sector, there are three important variables that have to be taken into account: the time, the cost and the quality of work. If the deadline is short and the cost is cheap the labor quality is generally poor. In addition, due to the different types of structures and various techniques of demolition, demolition work is more complicated [8]. According to reports on hospital records of the Australian Institute of Health and Welfare (AIHW), in 201383 of 8,300 occupational accidents in the construction sector in Australia between the years 2006 and 2009 happened on demolition sites (Figure 1) [9]. According to the research of the British Market Research Bureau into construction workers in England, 3.2\% of the 5,813 accidents reported happened on demolition sites. According to the research, the rate of accidents on demolition sites is lower than the other working sites, but the rate of accidents per demolition site is higher [10]. 


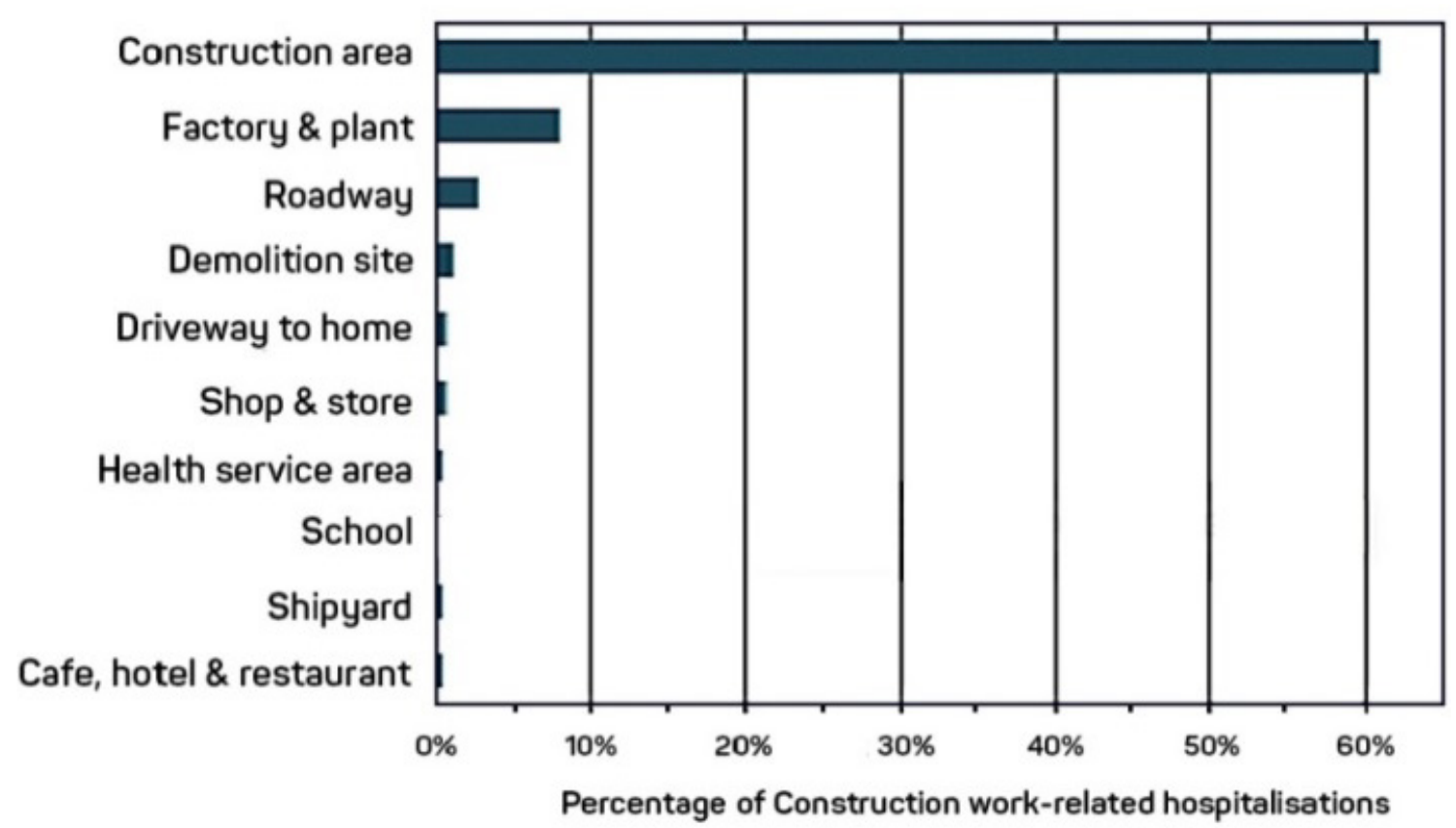

Figure 1. The ratio of accidents in the construction sector of Australia between the years 2006 and 2009 (Source: Australian Institute of Health and Welfare, 2013 - AIHW)

Gürcanlı and Müngen (2013) made a statistical point in terms of what happens to workers involved in accidents in Turkey. They indicated in their study that falling from heights is a common accident in the construction sector. It is inferred that the severity of the accidents in demolition work is quite high [11]. In another study by Gürcanlı (2006), he classified accidents in the construction and demolition industries between the years 1968 and 1999 according to witness reports analyzed by science academics [12]. The researchers believe that the accident data obtained from the Turkish Statistical Institute and Social Security Institution are not precise enough. Because of this it is difficult to determine whether the accidents occurred on demolition worksites or general construction worksites. As a result, the scientists state that they had to reach their own conclusion as to whether the accidents occurred on either demolition worksites or general construction worksites. Even so, the obtained data are considered to be useful and are used in scientific studies.

In the United States, there is insufficient information specifically stating the number of injuries and fatalities occurring in demolition work [13]. OSHA indicates that nearly 1,000 citations were issued for violations of OSHA's construction demolition standards between 2009 and 2013. The citations issued resulted from a failure to conduct an engineering survey determining the state of the structure before demolition [14]. In the United States 945 demolitions occurred and 11,615 workers were employed in the industry in 1994 [15].

Another important factor is the cost of demolition work accidents. According to a study by WorkSafeBC (The Workers' Compensation Board of British Columbia), three mechanisms of injury account for a high percentage of claims and an equally high percentage of costs [16]. In the United States the demolition companies struggled as a result of the housing market collapse and recession between 2008 and 2013. The demolition industry revenue is projected to fall at a yearly rate of $1.7 \%$ during the five years to 2013 to \$2.9 billion [17].

According to the above research, demolition work in the construction industry is very hazardous and the area in which fatal and non-fatal occupational injuries occurs most frequently. In this article, demolition work is discussed in terms of occupational health and safety and occupational accidents in demolition work are reviewed. There are limited databases in terms of occupational health and safety. The accidents classified are taken from all 653 occupational accidents in demolition work registered in 1984-2012 in the workers' section by the US Occupational Safety and Health Administration (OSHA). The OSHA database is a strong and effective source in terms of safety and health because employers must report all work-related fatalities and hospitalization to OSHA within 24 hours. In OSHA, the Standard Industrial Classification (SIC) System demolition work is classified in Heavy Construction, Not Elsewhere Classified (SIC Code: 1629) and Wrecking and Demolition Work (SIC Code: 1795). In the analyzed records, each kind of hazard in demolition work is evaluated with regard to different work procedures and the results are shown.

\section{Demolition Work in Terms of Health and Safety}

Demolition is defined and/or stated in the various standards of different countries [18-21]. "Demolition work" 
means complete or partial destruction, dismantling, wrecking or taking out any structural member of a building.

Demolition work (demolishing or dismantling buildings or other structures) is one of the most dangerous types of work and the severity of accidents in demolition work is quite high. Due to this highly risky work, at the project planning phase very serious measures should be taken in demolition work especially in terms of safety. A good demolition project should be prepared with a good plan predicting the hazards beforehand. Design, planning and implementation are the three basic stages of a demolition project and should be considered as projects independent of each other [22]. Health and safety measures are to be taken at each stage and should be studied considering the significant factors in Figure 2. After defining those factors, the health and safety management strategies to be implemented should be determined.

\section{Asbestos Exposure}

Another matter that needs to be emphasized in demolition work is asbestos exposure. It is known that asbestos was used in concrete and filling ingredients in most old structures. It is a well-known fact that asbestos spreads in the air as small crystal needles and causes cancer. A person can get cancer if he inhales asbestos particles in the air as the asbestos particles will settle in the lungs. Therefore, an investigation should be made to determine whether there is asbestos residue in the building to be demolished before the demolition work is done [23].

According to data from the World Health Organization, 125 million people around the world are exposed to asbestos in the workplace and 90,000 people die every year because of cancer caused by asbestos. The International Labor Organization stated for the first time that asbestos causes cancer in the supplementation of the "Occupation and Health Encyclopedia" published in 1938, which included a regulation concerning asbestos only. The International Labor Organization's Asbestos Convention No. 162 [24] and Asbestos Recommendation No. 172 [25] included legislation concerning the issues of asbestos usage, workers' exposure to asbestos and general measures to be taken in work involving asbestos. At the International Labor Conference in 2006, the International Labor Organization decided to ban the use of asbestos around the world. After this decision taken by the International Labor Organization, the World Health Organization adopted a text entitled "Elimination of Asbestos-related Diseases" in October 2006 [26]. In the document the World Health Organization points out that asbestos may cause cancer even at very low rates of exposure.

Before the 1980s, for reasons of physical and chemical convenience, asbestos was frequently used in construction all around the world. It was used in almost all areas of construction. Only glass, solid wood, doors, stone and bricks were not composed of asbestos. Although asbestos has been banned in many countries after the realization of its danger to health, there is still asbestos in many buildings that were built in the past and the likelihood of workers being exposed to asbestos is quite high in all kinds of maintenance, repair, restoration and demolition work in those buildings [27].

\section{Materials and Methods}

This study started with a literature review by searching several data bases [19, 28-31] and sources [18, 20, 32-38]. The search included the key descriptions: occupational accidents; construction accidents; demolition work; demolition accidents; occupational safety; occupational safety in construction; accident analysis; occupational accidents in demolition work and accident analysis in demolition work. Based on the literature, the types and classifications of accidents occurring in the construction sector and demolition work are inspected. In Table 1, the kinds of hazards that exist in work procedures are shown based on inspected accident reports and literature searches [10-12, 18-21, 28, 39-40].

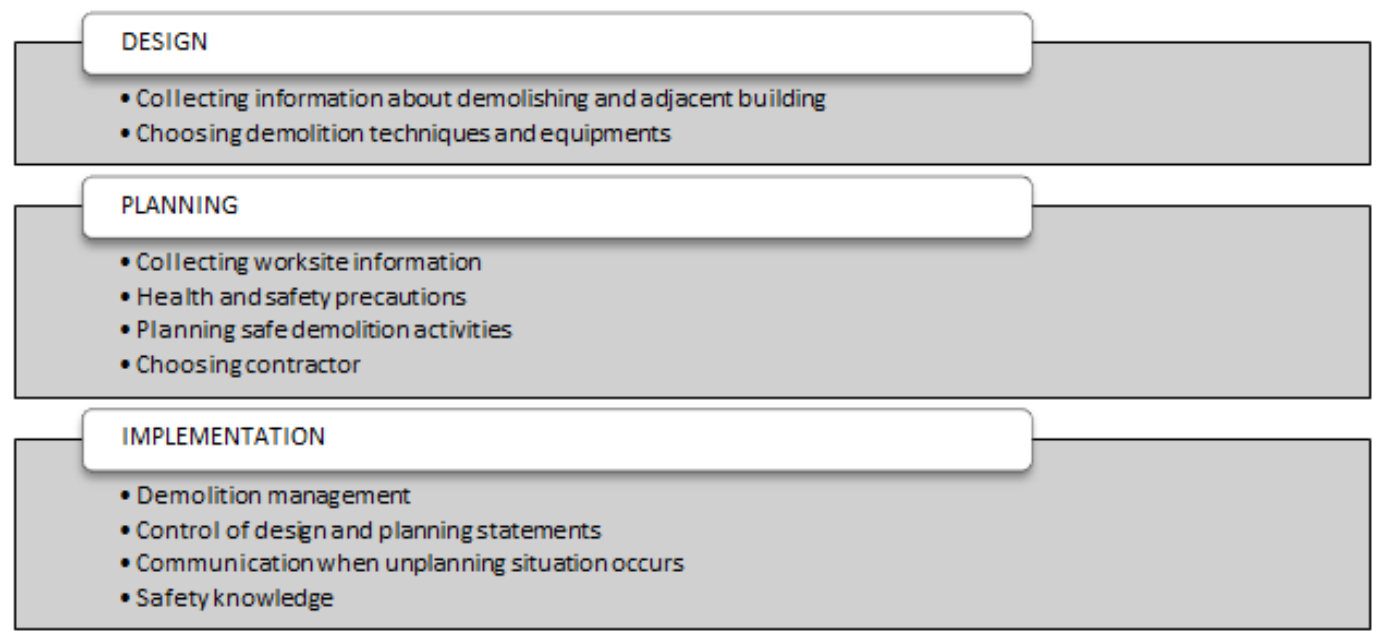

Figure 2. Significant health and safety factors during the demolition process phases 
Table 1. The kinds of hazards occurring in the work procedures

\begin{tabular}{|c|c|}
\hline Demolition Work Procedures & Accident Type* \\
\hline 1. Exposure to Asbestos & 1 \\
\hline 2. Compressed Air and Air-operated devices & 6,7 \\
\hline \multicolumn{2}{|l|}{ 3. Control of Chemicals Hazardous to Health } \\
\hline 4. General Demolition Procedure & $2,3,10$ \\
\hline \multicolumn{2}{|l|}{ 5. Dust } \\
\hline 6. Demolition Machines & $3,6,7,8,10$ \\
\hline 7. Risk of Fire (Work of Demolition and Dismantling) & 9 \\
\hline 8. Demolition without Machines (Manual) & $4,5,7$ \\
\hline 9. Hand Tools & 5,7 \\
\hline 10. Fencing & $4,5,7$ \\
\hline 11. Working at Height & $2,3,4,7,10$ \\
\hline 12. Active Services in the Area & 3 \\
\hline 13. Manual Operation & 5 \\
\hline \multicolumn{2}{|l|}{ 14. Noise - General } \\
\hline 15. Working near Roads and Sidewalks & 8 \\
\hline 16. Mobile Scaffolding & $2,3,7,10$ \\
\hline 17. Slipping, Tripping and Falling & 4,5 \\
\hline 18. Soft Dismantling Work in Buildings & $4,5,7,10$ \\
\hline \multicolumn{2}{|l|}{ 19. Third Parties and the Public } \\
\hline 20. Working on Mobile Elevating Work Platforms & $2,3,7,10$ \\
\hline 21. Loading Containers & $2,6,7,8$ \\
\hline 22. Hand Contact with Broken Glass & $4,5,7$ \\
\hline 23. Working on Stairs & 3,4 \\
\hline 24. Manually Operated Grinders & 5,7 \\
\hline 25. Dismantling Asbestos & $1,5,10$ \\
\hline 26. Working with Vibratory Compactors & 7 \\
\hline 27. Excavations & $2,3,7$ \\
\hline 28. Remote Demolition of Buildings & $2,3,6,7,8$ \\
\hline 29. Crushing and Grinding of Materials & $6,7,10$ \\
\hline 30. Dismantling of Steel Constructions & $2,3,6,7$ \\
\hline \multicolumn{2}{|l|}{ 31. Environmental Effects } \\
\hline \multicolumn{2}{|l|}{ 32. Personal Protective Equipment } \\
\hline 33. Demolition - Falling Materials & 7 \\
\hline 34. Traffic Management & $6,7,8$ \\
\hline
\end{tabular}


Table 2. OSHA Demolition accident search results

\begin{tabular}{|c|c|c|l|}
\hline No & Event Date & Fatality & Event Description \\
\hline 1 & $11 / 7 / 2014$ & $\mathrm{X}$ & Water Tank Crushes Employee \\
\hline 2 & $10 / 19 / 2011$ & & Employee Fractures Ankle by Falling Off an Elevated Platform \\
\hline 3 & $10 / 18 / 2011$ & $\mathrm{X}$ & Employee Dies After Wall Collapses \\
\hline 4 & $10 / 15 / 2011$ & $\mathrm{X}$ & Employee Is Killed in Wall Collapse \\
\hline 5 & $09 / 27 / 2011$ & $\mathrm{X}$ & Drywall Installer Is Electrocuted \\
\hline 6 & $09 / 15 / 2011$ & $\mathrm{X}$ & Employee Is Killed When Impaled on Rebar \\
\hline 7 & $09 / 14 / 2011$ & & Multiple Employees Are Injured in Scaffold Collapse \\
\hline 8 & $08 / 30 / 2011$ & & Two Employees Injured in Amusement Ride Removal \\
\hline 9 & $06 / 23 / 2011$ & $\mathrm{X}$ & Employees Fall as Trusses Collapse \\
\hline 10 & $06 / 20 / 2011$ & $\mathrm{X}$ & Employee Is Electrocuted \\
\hline 11 & $04 / 26 / 2011$ & $\mathrm{X}$ & One Employee Crushed, One Employee Injures Leg in Collapse \\
\hline 12 & $04 / 08 / 2011$ & $\mathrm{X}$ & Employee Is Killed by Fall Through Skylight \\
\hline 13 & $03 / 01 / 2011$ & & Employee's Foot Is Amputated When Struck by Steel Beam \\
\hline 14 & $02 / 13 / 2011$ & & Employee Is Injured When Hit by Falling Hull \\
\hline 15 & $01 / 04 / 2011$ & $\mathrm{X}$ & Employee Is Killed When Crushed Under Collapsed Wall \\
\hline 16 & $12 / 28 / 2010$ & & Employee Fractures Back While Falling from Ladder \\
\hline 17 & $12 / 27 / 2011$ & & Employees Are Injured Falling from Roof \\
\hline 18 & $12 / 14 / 2010$ & $\mathrm{X}$ & Employee Is Killed When Struck by Refrigerator \\
\hline 19 & $12 / 08 / 2010$ & & Four Employees Are Injured in Explosion in Confined Space \\
\hline 20 & $12 / 07 / 2010$ & & Employee Is Injured in Partial House Collapse \\
\hline
\end{tabular}


Table 3. Accident types in terms of work procedures

\begin{tabular}{|c|c|c|c|c|c|c|c|c|c|c|c|c|c|}
\hline $\begin{array}{c}\text { Work } \\
\text { Procedures }\end{array}$ & 1 & 2 & 3 & 4 & 5 & 6 & 7 & 8 & 9 & 10 & 11 & 12 & \\
\hline $\begin{array}{c}\text { Work } \\
\text { Procedures / } \\
\text { Hazards }\end{array}$ & $\begin{array}{l}\text { 1. General } \\
\text { Demolition } \\
\text { Procedure }\end{array}$ & $\begin{array}{l}\text { 2. Demolition } \\
\text { Machines }\end{array}$ & $\begin{array}{l}\text { 3. Demolition } \\
\text { of Steel } \\
\text { Constructions }\end{array}$ & $\begin{array}{c}4 . \\
\text { Working } \\
\text { with Stairs }\end{array}$ & $\begin{array}{l}\text { 5. Manual } \\
\text { Operation }\end{array}$ & $\begin{array}{c}\text { 6. Active } \\
\text { Services } \\
\text { in the } \\
\text { Area }\end{array}$ & 7. Fire & $\begin{array}{l}\text { 8. Mobile } \\
\text { Scaffolding }\end{array}$ & $\begin{array}{l}\text { 9. Working } \\
\text { at Heights }\end{array}$ & $\begin{array}{c}10 . \\
\text { Demolition- } \\
\text { Falling } \\
\text { Materials } \\
\end{array}$ & $\begin{array}{c}11 . \\
\text { Asbestos }\end{array}$ & 12. Others & Total \\
\hline $\begin{array}{l}\text { 1. Collapse } \\
\text { of Buildings }\end{array}$ & 165 & 0 & 15 & 0 & 0 & 0 & 0 & 3 & 0 & 0 & 0 & 1 & 184 \\
\hline $\begin{array}{c}\begin{array}{c}\text { 2. Falling } \\
\text { from Heights }\end{array} \\
\end{array}$ & 119 & 5 & 9 & 0 & 1 & 0 & 0 & 8 & 27 & 0 & 0 & 0 & 169 \\
\hline $\begin{array}{l}\text { 3. Struck by } \\
\text { Falling } \\
\text { Objects }\end{array}$ & 65 & 29 & 14 & 0 & 5 & 0 & 0 & 1 & 1 & 10 & 0 & 5 & 130 \\
\hline $\begin{array}{l}\text { 4. Falling } \\
\text { /Slipping } \\
\text { /Stumbling }\end{array}$ & 2 & 0 & 1 & 28 & 1 & 0 & 0 & 0 & 0 & 0 & 0 & 7 & 39 \\
\hline $\begin{array}{l}\text { 5. Asbestos } \\
\text { Exposure }\end{array}$ & 0 & 0 & 0 & 0 & 0 & 0 & 0 & 0 & 0 & 0 & 3 & 0 & 3 \\
\hline $\begin{array}{l}\text { 6. Electric } \\
\text { Shock }\end{array}$ & 1 & 1 & 0 & 0 & 0 & 16 & 0 & 0 & 0 & 0 & 0 & 0 & 18 \\
\hline 7. Fire & 0 & 0 & 0 & 0 & 0 & 0 & 16 & 0 & 0 & 0 & 0 & 0 & 16 \\
\hline $\begin{array}{l}\text { 8. Machine } \\
\text { Accidents }\end{array}$ & 0 & 54 & 0 & 0 & 0 & 0 & 0 & 2 & 3 & 0 & 0 & 3 & 62 \\
\hline $\begin{array}{l}\text { 9. Traffic } \\
\text { Accidents }\end{array}$ & 0 & 1 & 0 & 0 & 0 & 0 & 0 & 0 & 0 & 0 & 0 & 1 & 2 \\
\hline $\begin{array}{l}\text { 10. Cuts } \\
\text { /Scratches }\end{array}$ & 0 & 0 & 0 & 0 & 13 & 0 & 0 & 0 & 0 & 0 & 0 & 0 & 13 \\
\hline 11. Others & 4 & 0 & 0 & 0 & 0 & 0 & 0 & 0 & 0 & 0 & 0 & 13 & 17 \\
\hline Total & 356 & 90 & 39 & 28 & 20 & 16 & 16 & 14 & 31 & 10 & 3 & 30 & 653 \\
\hline
\end{tabular}




\subsection{Data Collection from the Accident Reports}

The sources of data are official statistics and records archived by the US Occupational Safety and Health Administration (OSHA) [41]. The material collected by OSHA shows the work-related injuries and sickness data obtained from companies within specific industries as well as the employment size specifications.

On December 29, 1970, the Occupational Safety and Health Act of 1970 (OSH Act) was introduced into US law and OSHA was established. OSHA's safety and health standards, including those for asbestos, fall protection, cotton dust, trenching, machine guarding, benzene, lead and blood-borne pathogens have prevented countless work-related injuries, illnesses and deaths. The OSH Act protects most private sector employers and their employees in addition to some of the public-sector employers and employees in the 50 states of the US. OSHA's sources of information are data provided by the Bureau of Labor Statistics, Department of Labor, and OSHA's Area Offices.

The Accident Investigation Search page allows us to search OSHA's Integrated Management Information System (IMIS) enforcement database for casualties that contain specified terms. This is obtained from the Accident Investigation (OSHA-170) form. The database is updated daily. In the past, the term "accident" was regarded as an unplanned, unwanted event. To many, "accident" suggests an event that was random, and could not have been prevented. Since nearly all worksite fatalities, injuries, and illnesses can be prevented, OSHA suggests using the term "incident" investigation. Incident investigations are those that focus on determining and correcting root causes, not on finding fault or blame.

This study analyzes all 653 demolition accident records archived by OSHA from 1984 until 2012. Table 2 shows the description of 20 of these 653 demolition accident reports.

\subsection{Classification of Accidents}

From the demolition accident search results, we see the damage caused by the accident (fatal or non-fatal), the main causes of the accidents (collapse, fire, etc.) and the demolition work procedures. Furthermore, important types of demolition accident are classified according to the demolition work procedures (Table 3)

The 10 types of hazards shown in Table 3 are a result of the 34 different types of work procedures shown in Table 1 . These hazards are based on actual accidents. Also, the 34 different types of work procedures shown in Table 1 have been summarized to the 12 work procedures shown in Table 3 . The most common work procedures have been reduced to 11 and the 23 different work procedures shown in Table 1 fall under "other" in Table 3 . The total is 12. The summarization occurred for the following two reasons. The first is that $95 \%$ of all accidents occur as a result of the 11 kinds of work procedures shown in Table 3. The other reason is that the accidents occurring as a result of the "other" work procedures already exist in the 11 work procedures. For instance, one of the work procedures, "General demolition procedure", has the hazard of "Falling from heights". However, "Working at heights" is already a sub-procedure of the "General demolition procedure". If an evaluation is to be made considering the previous studies it can be seen that the rate of accidents in demolition work in the construction sector has increased [11, 12]. While falling is the first in the rank of the results of accidents in construction in general, the collapse of buildings is the first in demolition work. It is stated that falling from heights and falling objects come next as the most common accident types according to the research of the 653 accident reports of hazards causing death, injury or any kind of health problems. It can be easier to take advantage of that data with checklists focused on hazards. For instance, looking at the statistics in Figure 3, it can be seen that $49 \%$ of accidents resulting in death are caused by the collapse of buildings. On the other hand, according to Figure 4, the percentage of fatalities in harming the other workers on site is $45 \%$ and the percentage of fatalities in falling/hitting objects is $31 \%$. According to this the fatality rate in harming the other workers is higher than the fatality rate in falling/hitting objects. These data give stronger information about what kinds of accidents happen in what kinds of work procedures.

\section{Results and Discussion}

In the statistics on occupational accidents made by the 16th International Conference of Labor Statisticians, concepts like accident frequency rate, accident severity rate and accident probability rate are defined. According to the resolutions adopted at the conference, the following considerations were made pertaining to occupational injuries [42]:

- Total number of incidents

- Number of fatal incidents

- Number of non-fatal incidents

- Number of temporary incapacities 


\section{General Demolition Procedure}

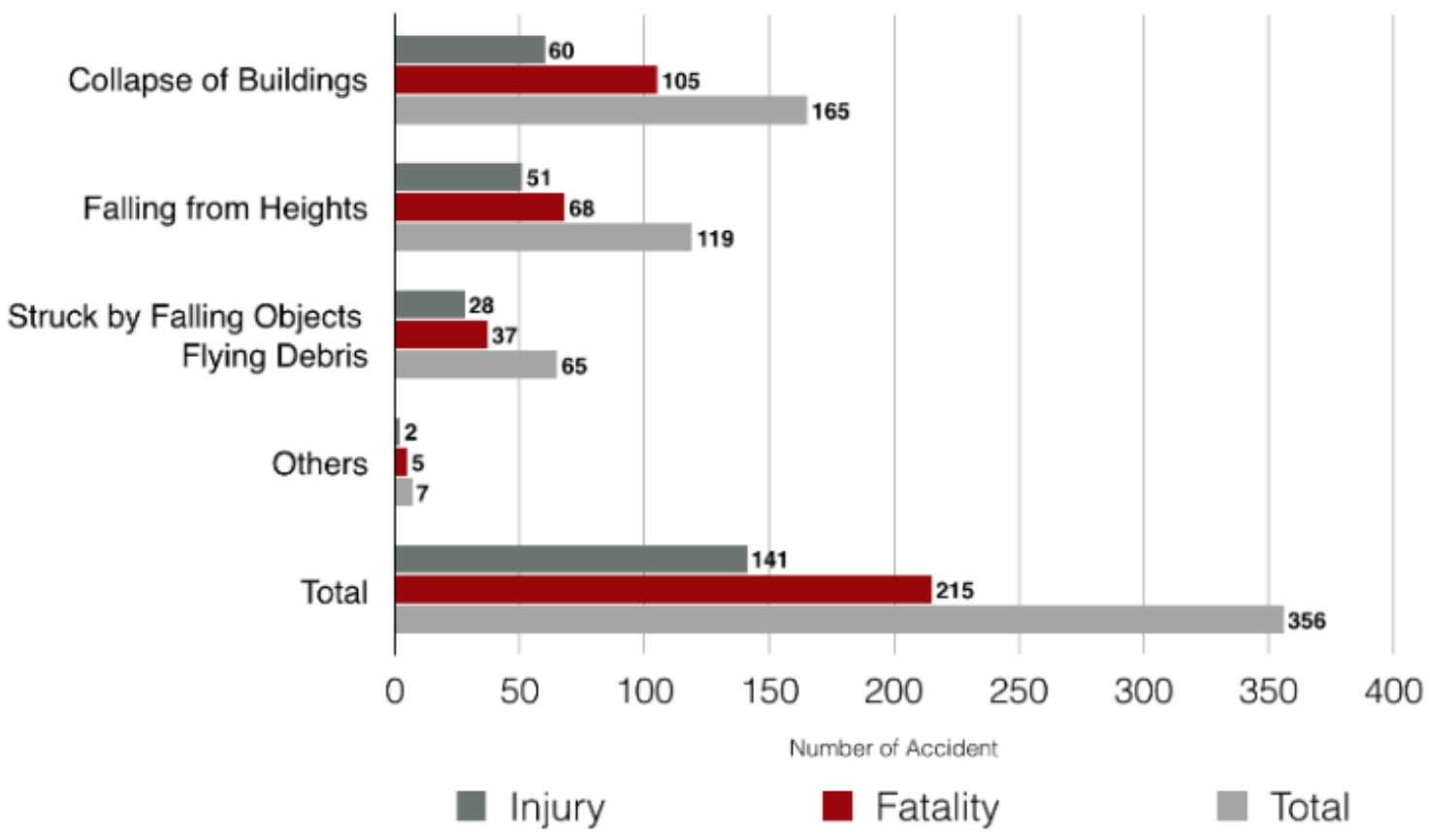

Figure 3. Number of accidents resulting in death or injury in general demolition procedure

\section{Demolition Machines}

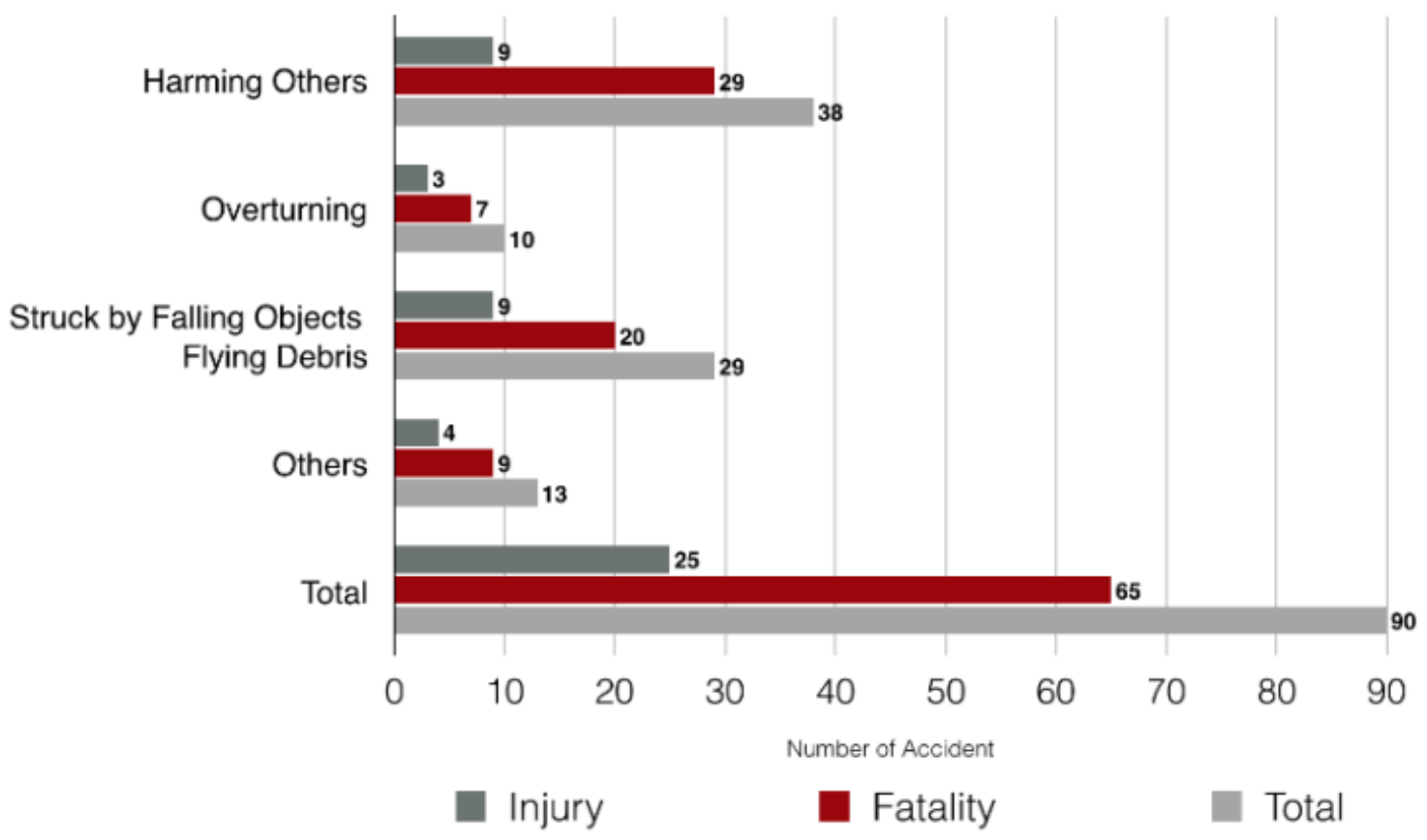

Figure 4. Number of accidents resulting in death or injury caused by demolition machines 


\subsection{Table Numbering \& Citations}

The above mentioned considerations can provide extensive information to help assess the severity potential. The severity of workplace accidents and the possibilities are important factors in understanding occupational accidents. For example, Figure 5 shows demolition fatalities between the years of 1984 and 2012 in the US. Companies can use this information to prioritize their occupational focus when assessing the severity of potential accidents. The most frequently occurring fatal accidents are shown in Figure 6. According to Figure 5 and Figure 6, demolition work has a high rate of occupational fatality. Most of fatalities are caused by the collapse of buildings, falling from heights, machine accidents and electrocutions.

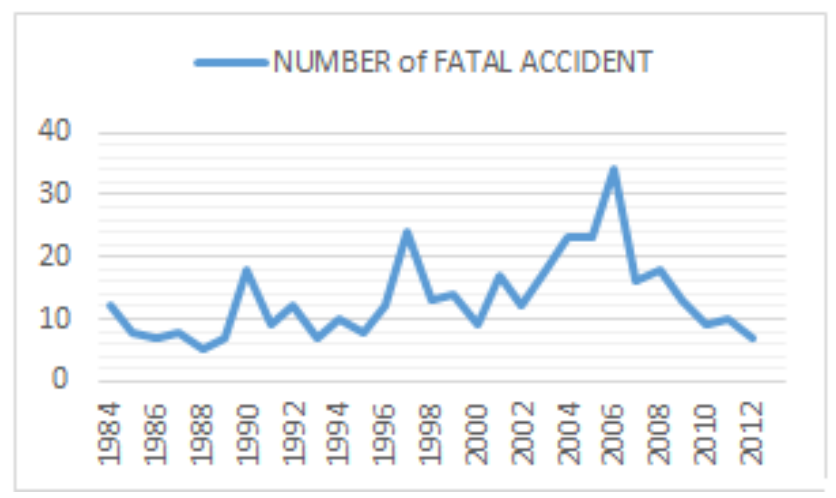

Figure 5. Demolition fatalities

FATAL ACCIDENTS

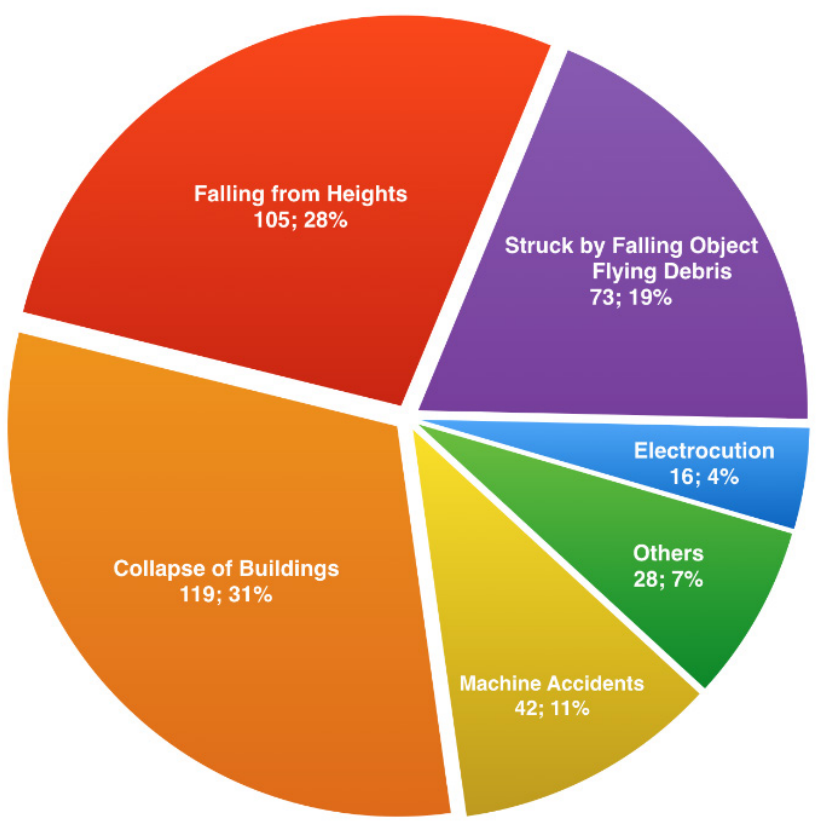

Figure 6. Fatal accidents
The above figures do not show the safety precautions in demolition work. However, with these data there can be a strategy made in order to deal with injuries caused in demolition work and to prevent those accidents from occurring.

It is difficult to calculate the possibility of accidents in demolition work in the construction industry because of the existing reporting systems. This is because the reporting systems are generally for continuously repeated tasks in other sectors and therefore the above mentioned concepts are not suitable for the construction sector in which there are lots of uncertainties. In the construction sector, even if two construction projects are same as each other, they differ because of the uncertainties of the construction sector. There are studies in literature that prove that accidents at each worksite can be very different from each other [43]. The studies show that it is possible to find several descriptions and evaluations of the accident probability [44-50]. In Table 4, there are fatal accidents, injury accidents and annual average of accidents in demolition work according to the 653 accident reports recorded between the years of 1984 and 2012 by the workers' section of US Occupational Safety and Health Administration (OSHA). As we can see in Table 4, the rates shown by percentages give a good idea of the severity and probability of accidents.

In the study, the value of the accident probability is reached by calculating the percentage of accident types in occupational accidents occurring in demolition work. As a result, we can calculate the probability of all types of accidents according to the types of work procedures. According to the 653 accident reports the different types of accidents were classified in terms of demolition work, and the number and the rate of the accidents were found. A classification was made according to insufficient data and it was not suitable for reaching a complete conclusion, but it makes it possible to evaluate the situation of occupational safety in demolition work in general. According to Table 3, the rate of the probability of accidents according to the collapse of buildings is $28.79 \%$. It is also shown that "total fatal accidents" number 383 and the majority of these accidents occurred in the "collapse of buildings" and "falling from heights", so precautions have to be taken while working in these procedures. In one year the total average number of accidents was $23.32 \%$ and $6.71 \%$ were due to the collapse of buildings.

In order to accomplish safe demolition an inspection should be done with the help of hazard checklists [51]. With the help of hazard checklists, the probability of accidents will be reduced in demolition work. Hazard checklists also make it possible to do a risk analysis before each job that has risk. 
Table 4. Number of accident types and accident probability

\begin{tabular}{|c|c|c|c|c|c|c|c|}
\hline Accident Report & $\begin{array}{c}\text { Fatal } \\
\text { Accident }\end{array}$ & $\%$ & $\begin{array}{c}\text { Injury } \\
\text { Accident }\end{array}$ & $\%$ & $\begin{array}{c}\text { Total } \\
\text { Accident }\end{array}$ & $\begin{array}{c}\text { Average } \\
\text { Accidents in a } \\
\text { Year }\end{array}$ \\
\hline Collapse of buildings & 119 & $31,07 \%$ & 69 & $25,56 \%$ & 188 & $28,79 \%$ & 6,71 \\
\hline Falling from Heights & 105 & $27,42 \%$ & 66 & $24,44 \%$ & 171 & $26,19 \%$ & 6,1 \\
\hline Struck by Falling Objects/Flying Debris & 73 & $19,06 \%$ & 57 & $21,11 \%$ & 130 & $19,91 \%$ & 4,64 \\
\hline Machine Accidents & 42 & $10,97 \%$ & 14 & $5,19 \%$ & 56 & $8,58 \%$ & 2 \\
\hline Slipping/Tripping/Falling/Stumbling & 14 & $3,66 \%$ & 25 & $9,26 \%$ & 39 & $5,97 \%$ & 1,39 \\
\hline Electric Shock & 16 & $4,18 \%$ & 2 & $0,74 \%$ & 18 & $2,76 \%$ & 0,64 \\
\hline Fire & 3 & $0,78 \%$ & 13 & $4,81 \%$ & 16 & $2,45 \%$ & 0,57 \\
\hline Cuts/Scratches/Jamming/Hitting/Puncturing/ & 2 & $0,52 \%$ & 11 & $4,07 \%$ & 13 & $1,99 \%$ & 0,46 \\
\hline Manual Handling & 1 & $0,26 \%$ & 1 & $0,37 \%$ & 2 & $0,31 \%$ & 0,07 \\
\hline Traffic Accidents & 0 & $0,00 \%$ & 3 & $1,11 \%$ & 3 & $0,46 \%$ & 0,11 \\
\hline Asbestos Exposure & 8 & $2,09 \%$ & 9 & $3,33 \%$ & 17 & $2,60 \%$ & 0,61 \\
\hline Others & 383 & $100,00 \%$ & 270 & $100,00 \%$ & 653 & $100,00 \%$ & 23,32 \\
\hline
\end{tabular}

Table 5. The comparison of demolition accidents and overall construction accidents

\begin{tabular}{|c|c|}
\hline \multicolumn{2}{|c|}{ Fatal Demolition Accidents } \\
\hline Cause of Accident & \% In Demolition \\
\hline 1. Collapse of Buildings & 31,1 \\
\hline 2. Falls & 27,4 \\
\hline 3. Struck by Objects & 19,1 \\
\hline 4. Machine Accidents & 10,1 \\
\hline
\end{tabular}

\begin{tabular}{|c|c|}
\hline \multicolumn{2}{|c|}{ Fatal Construction Accidents } \\
\hline Cause of Accident & \% In Overall Construction \\
\hline 1. Falls & 39,9 \\
\hline 2. Electrocutions & 8,5 \\
\hline 3. Struck by Objects & 8,4 \\
\hline 4. Caught-in/between & 1,4 \\
\hline
\end{tabular}

\subsection{Most Frequent Demolition Accidents}

According to the results from OSHA, the demolition accident reports show that six of the most frequent accidents are collapse of buildings, falling from heights, struck by falling objects/flying debris, machine accidents, electric shocks and slipping/tripping/falling/stumbling. Together they are responsible for $96.36 \%$ of all fatalities in demolition work in the US. The most frequent accident causing fatalities is the collapse of buildings/structures. The factors that lead to the collapse of buildings are employees not knowing the stability of the structures, employees being at the wrong place at the wrong time during demolition work, incorrect setup and early disassembling of scaffolds. All these are the general causes of collapse during demolition work. Therefore, a supervisor must be appointed during the demolition work and it should be someone who is highly experienced in both demolition work and building construction. Before proceeding with the demolition work the supervisor should carefully examine the building plan of the property. If the building plan is not provided the supervisor should make a survey to identify the structural type so that the demolition work can be constructively planned. After examining the building plan, a proper demolition method can be chosen and the supervisor should lay out the working process to the employees and other operatives. The supervisor should not only explain the working process but also explain the safety risks involved and how to prevent the risk from occurring. Supervision should be done continuously.

Falling from heights can be categorized by the following factors: falling through fragile material, falling from edges and holes, falling from ladders and falling from scaffolds or work platforms.

Figure 4 divides the "Machine accidents" category into separate types of accidents. Most machine accidents are caused by harming others, being struck by falling objects and overturning. This is because workers don't follow the rules and regulations and it is suggested that there should be more signboards on worksites to increase awareness of accidents. Due to technology machines are used in demolition work and have improved safety and security. In the demolition sector, the use of machines has increased work efficiency and reduced the number of people needed to perform many tasks. However, this also created another hazard, which is being "struck by" workplace machinery. Due to the likelihood of human error these hazards are named man machine interface.

As can be seen from Table 5, the trend of demolition related fatal accident causes is different as compared to the trend of overall fatal construction accident causes. The data 
for overall construction accidents taken from OSHA accident reports is commonly known as "Fatal four" [52].

The rates of accidents in the construction sector and during demolition work are regarded as high. However, accidents can be prevented with the use of appropriate safety measures. Reducing accidents and studying the effect of safety measures in demolition work must begin with an understanding of the causes, origins and patterns of construction accidents. Two of the main reasons behind demolition accidents are unsafe working conditions and incorrect actions. Demolition accidents can be prevented by determining the main factors leading to accidents, techniques such as the theory of an accident and human error to determine why accidents occur. [35]. The main reasons for unsafe working conditions are the following: (1) Unsafe working conditions are a natural factor on a demolition site, (2) nonhuman related event(s), (3) incorrect actions of employees or coworkers and (4) management actions. A worker can make mistakes whether the conditions are safe or not. For example, taking the decision to proceed to work in dangerous conditions; not wearing appropriate personal protective equipment such as a hard hat or safety glasses; working while intoxicated, working with insufficient sleep etc. [53]. OSHA stated that accidents can be reduced by the elimination of hazards, substitution, engineering control, administrative control and using personal protective equipment [54]. According to the most frequent fatal demolition accidents that can be seen in Table 5 , it is suggested to prepare a checklist in the "what-why-how" manner to prevent demolition work accidents. Table 6 shows an implementation in "what-why-how" manner for the collapse of buildings, falls, struck by objects and machine accidents in the OSHA demolition accident reports.

Table 6. The Preparation of the "what-why-how" checklist for most frequent demolition accidents

\begin{tabular}{|c|c|}
\hline \multicolumn{2}{|c|}{ WHAT (Cause/Hazard of Accident): Collapse } \\
\hline$\frac{\text { WHY (It happens }}{\text { - hazards) }}$ & $\underline{\text { HOW }}$ (To prevent or reduce) \\
\hline $\begin{array}{l}\text { Lack of } \\
\text { information } \\
\text { about the whole } \\
\text { or part of the } \\
\text { structure }\end{array}$ & $\begin{array}{l}\text { 1. A structural survey should be carried out prior to demolition. } \\
\text { 2. Relevant information must be provided by the client in an appropriate form. }\end{array}$ \\
\hline $\begin{array}{l}\text { Caused by } \\
\text { strong winds, } \\
\text { instability or } \\
\text { overloading of } \\
\text { scaffolds }\end{array}$ & $\begin{array}{l}\text { 1. Working at heights should not be carried out in adverse weather conditions. } \\
\text { 2. Safe working load should not be exceeded. } \\
\text { 3. Scaffold structures should have a safe base and appropriate height measures. } \\
\text { 4. All scaffold structures should be tied, braced and stabilized in a safe way. } \\
\text { 5. Safe working platforms should be inspected regularly. }\end{array}$ \\
\hline $\begin{array}{l}\text { Overload or } \\
\text { structural } \\
\text { failure due to } \\
\text { incorrect } \\
\text { installation of } \\
\text { scaffolds. }\end{array}$ & $\begin{array}{l}\text { 1. Ensure regular inspection and the maintenance of scaffolds. } \\
\text { 2. Only trained operatives are to set up, alter or dismantle scaffolds. } \\
\text { 3. Scaffolds must be marked with a safe working load and this must not be exceeded. }\end{array}$ \\
\hline \multicolumn{2}{|c|}{ WHAT (Cause/Hazard of Accident): Falls } \\
\hline $\begin{array}{l}\frac{\text { WHY }}{\text { - hazards) }} \\
\end{array}$ & $\underline{\text { HOW }}$ (To prevent or reduce) \\
\hline $\begin{array}{l}\text { Operatives } \\
\text { falling from } \\
\text { scaffolds, } \\
\text { roofs, MEWPs } \\
\text { etc. due to } \\
\text { several reasons. }\end{array}$ & $\begin{array}{l}\text { 1. Working at heights should only be performed when no other practicable option is available. } \\
\text { 2. Working at heights risk assessment should be carried out. } \\
\text { 3. Some measures should be taken, e.g. safe working platforms, edge protection and fall protection. } \\
\text { 4. Safe working platforms should be inspected regularly. } \\
\text { 5. Wherever possible a safe working platform should be set up by trained personnel. } \\
\text { 6. Fragile roof areas should be protected or access to the area should be prohibited. Edge protection should be set } \\
\text { up at all open edges where falls could occur. } \\
\text { 7. All operatives should wear appropriate personal protective equipment and safety footwear. } \\
\text { 8. Operatives should wear a full body safety harness and restraint lanyard attached to a suitable anchor point } \\
\text { when a fall is possible. } \\
\text { 9. Where fall arrest equipment is used, a rescue procedure and equipment must be available on site. } \\
\text { 10. Safety netting or air bags to be positioned underneath where restraint is impracticable }\end{array}$ \\
\hline $\begin{array}{l}\text { Falling caused } \\
\text { by demolition } \\
\text { machines }\end{array}$ & $\begin{array}{l}\text { 1. Machine operatives should wear seat belts and close the door when operating machinery. } \\
\text { 2. Activities involving climbing onto machines, i.e. access/egress to and from cabin, re-fueling etc., should be } \\
\text { carried out using proper means of safe access. }\end{array}$ \\
\hline $\begin{array}{l}\text { Falling from } \\
\text { working } \\
\text { platforms or } \\
\text { fragile surfaces }\end{array}$ & $\begin{array}{l}\text { 1. Working at heights risk assessment should be carried out. } \\
\text { 2. Safe working platforms should be provided and fragile surfaces protected. } \\
\text { 3. Falling restraint/arrest equipment should be provided as the last option. 4. Rescue facilities and trained } \\
\text { personnel should be on site where necessary. }\end{array}$ \\
\hline
\end{tabular}




\begin{tabular}{|c|c|}
\hline $\begin{array}{l}\text { Falling from } \\
\text { scaffolds } \\
\text { because of } \\
\text { human errors }\end{array}$ & $\begin{array}{l}\text { 1. Only trained personnel are to set up, alter or dismantle towers. } \\
\text { 2. Ensure regular inspection and the maintenance of scaffolding. } \\
\text { 3. All handrails must be correctly fitted. } \\
\text { 4. Precautions should be taken to avoid trespassers gaining access to the tower after hours. } \\
\text { 5. Access points such as trap doors must be kept shut while workers are on the platform. } \\
\text { 6. Access must be by a fixed internal ladder. }\end{array}$ \\
\hline $\begin{array}{l}\text { Falling from } \\
\text { ladders because } \\
\text { of human errors }\end{array}$ & $\begin{array}{l}\text { 1. The ladder should be positioned central to the job. No overreaching should be allowed. } \\
\text { 2. Ladders should be tied off where possible and footed if this is impractical. } \\
\text { 3. Ladders must be of industrial quality, in good condition and subject to regular inspections. } \\
\text { 4. Ladders should only be used for short duration tasks or when it is not practicable to use any other form of } \\
\text { access equipment. }\end{array}$ \\
\hline \multicolumn{2}{|c|}{ WHAT (Cause/Hazard of Accident): Struck By } \\
\hline $\begin{array}{l}\text { WHY }(\text { It } \\
\text { happens - } \\
\text { hazards) }\end{array}$ & $\underline{\text { HOW }}$ (To prevent or reduce) \\
\hline Falling Objects & $\begin{array}{l}\text { 1. The wearing of head protection on site should be compulsory. } \\
\text { 2. All air power tools must be checked before and after use. } \\
\text { 3. Only properly trained operatives should use pneumatic powered tools. } \\
\text { 4. The area below the work should be cordoned off and warning signs should be put in place. } \\
\text { 5. Where necessary debris netting should be set up. } \\
\text { 6. Falls from debris should be prevented by toe boards, chutes, netting, brick guards etc. } \\
\text { 7. Tools \& equipment should be hoisted with ropes or lifting equipment. }\end{array}$ \\
\hline Flying Objects & $\begin{array}{l}\text { 1. Operatives should wear all relevant personal protective equipment for the work to be carried out. } \\
\text { 2. Where guards have been fitted, they must be in good condition and securely fastened. } 3 \text {. The correct personal } \\
\text { protective equipment must be worn, including goggles or a full face shield } \\
\text { 4. Work should be organized to eliminate the need for operatives to be working below other demolition activities. }\end{array}$ \\
\hline \multicolumn{2}{|c|}{ WHAT (Cause/Hazard of Accident):Demolition Machine Accidents } \\
\hline $\begin{array}{l}\text { WHY (It } \\
\begin{array}{c}\text { happens - } \\
\text { hazards) }\end{array}\end{array}$ & $\underline{\text { HOW }}$ (To prevent or reduce) \\
\hline $\begin{array}{l}\text { Overturning of } \\
\text { the machine }\end{array}$ & $\begin{array}{l}\text { 1. Only operatives with experience and training in the relevant type of operation should operate demolition } \\
\text { machines. }\end{array}$ \\
\hline $\begin{array}{l}\text { Overloading of } \\
\text { the machine }\end{array}$ & $\begin{array}{l}\text { 1. All machines must meet with the prescribed test and inspection requirements and records must be readily } \\
\text { available. } \\
\text { 2. To prevent overloading, the manufacturers bucket size should never be exceeded. } \\
\text { 3. All machines should be fit for purpose, in good condition and suitably maintained. } \\
\text { 4. When other attachments are used weight/load assessments should be carried out to establish suitability. }\end{array}$ \\
\hline $\begin{array}{l}\text { Machine falling } \\
\text { into holes, } \\
\text { excavations or } \\
\text { cellars. }\end{array}$ & $\begin{array}{l}\text { 1. Machines should be prohibited near unsupported trenches. These areas should be clearly identified and barriers } \\
\text { should be set up. } \\
\text { 2. An assessment of the ground condition may need to be carried out to ensure suitability of the area for the } \\
\text { demolition machine operation. } 3 \text {. Where necessary, physical barriers, edge protection or vehicle stops must be set } \\
\text { up or installed. }\end{array}$ \\
\hline $\begin{array}{l}\text { Harming } \\
\text { Others }\end{array}$ & $\begin{array}{l}\text { 1. Carrying of passengers must be strictly prohibited. } \\
\text { 2. A banksman should be deployed to ensure all other personnel are kept clear of machine operations. } \\
\text { 3. Personnel should be kept away from machine operations by the banksman. } 4 \text {. To safeguard against flying or } \\
\text { falling debris, the site should be contained and trespassing in exclusion zones should be prohibited where } \\
\text { necessary. } \\
\text { 5. All machines to be fitted with ROP's protection around the operative's cab, plus grilles or similar should be } \\
\text { fitted to protect the windscreen and roof lights. } \\
\text { 6. Authorized personnel in the area of the machine's movements should wear high visibility clothing. }\end{array}$ \\
\hline
\end{tabular}

The danger of demolition work can be reduced and accidents prevented through correct planning, training, efficient standards and suitable personal protective equipment. Demolition work that is efficiently controlled can increase the safety of workers and the surroundings, which will then reduce injuries and accidents [55]. All demolition work should be planned efficiently before carrying out the work. Planning involves collecting worksite information, health and safety precautions, planning safe demolition activities and choosing the contractor. Personal protective equipment alone is not sufficient for demolition work; highly experienced knowledge is required for the proper use of equipment. Personal protective equipment selection, use, and maintenance are also important factors for construction management since demolition work frequently exposes workers to unique height risks. To maximize the protection of workers, safety nets, retractable lanyards, full body harnesses and specialized anchoring systems may be required [56]. The correct information, good instruction and training must be available for personnel to ensure that the work is done in a safe manner. Close supervision is required during training and in the work as operatives may lack experience and awareness of the dangers that may be encountered during the work. The demolition of buildings 
and structures should be performed according to the recommended standards.

\section{Conclusions}

According to the research, we can prove that demolition accidents can be categorized effortlessly. The demolition accidents data provided in the study give detailed information about the causes of accidents. $77.6 \%$ of accidents are caused by the collapse of buildings, falling from heights and being struck by falling/flying objects. The rate of accidents in the collapse of buildings can be reduced through proper supervision and experience in choosing the right demolition method. Even if the simplest and safest method is used in demolition work, accidents still occur according to the records. The prevention of falling from heights and "struck by" accidents can be maximized by the proper use of equipment and in some situations the prevention of falling materials should be a concern.

The information about safety risks in demolition work is limited. Because there are fewer studies focused on demolition safety, as a conclusion demolition work has generally been considered as a small area in the construction sector until now. It was also found that the most fatal and severe accidents occur in demolition work. This is why there should be more focus on demolition work. A better understanding of the safety risks in demolition work is therefore needed to reduce demolition-related accidents in the future. With increased development in countries, demolition work has become an important branch of the construction business and needs to be considered more. While the results of this study are based on very limited data, nevertheless it has shown that there are differences between injury trends in demolition work and construction work. Safety precaution methods during demolition work must differ from normal construction work and greater attention should be paid to how to bring down a building structure safely and how to avoid unintentional collapse.

Through the data gathered from this study, it can be concluded that proactive steps are required to overcome the safety issues in demolition work. The amount of demolition work is increasing every day.

There should be a common view of the hazards of demolition work. The method of demolition should be chosen to provide for health and safety concerns and not according to the existing tools and materials. In this respect, an effort can even be made to develop new demolition methods.

Most accidents are attributed to human causes and this is a trend that is likely to increase in proportion to the reliability and probable sophistication of the hardware tools. It is expected that the "safety climate" provided on worksites may reduce the number of accidents. Workers' social, psychological and financial aspects and also their working hours and health may be considered with regard to this climate.

Certain licenses and certificates should be required for companies and individuals doing demolition work. Not every individual or every company should be free to do demolition work, as they please. They should be subjected to certain criteria and qualifications. With the help of the easy-to-use "what-why-how" checklists, controlled safety measures should be compulsory on demolition sites and should be very practical.

\section{REFERENCES}

[1] Diven, R.; Taylor, M. R. Demolition Planning. In The Architect's Handbook of Professional Practice, Update 2006.; Demkin, J.A.; John Wiley \& Sons, Inc.: Hoboken, New Jersey, United States of America, 2006; pp. 143-157.

[2] Li, Y.; Li, Y.; Westlund, H.; Liu, Y. Urban-rural transformation in relation to cultivated land conversion in China: Implications for optimizing land use and balanced regional development. Land Use Policy 2015, 47, 218-224.

[3] Shaalan, I. Sustainable urban transformation in small cities in Egypt: a UN-habitat perspective. Journal of Cleaner Production 2013, 50, 200-204.

[4] Elicin, Y. Neoliberal transformation of the Turkish city through the Urban Transformation Act. Habitat International 2014, 41, 150-155.

[5] Wießner, R. Urban development in East Germany - specific features of urban transformation processes. GeoJournal 1999, $49,43-51$.

[6] McCormick, K.; Anderberg, S.; Coenen, L.; Neij, L. Advancing sustainable urban transformation. Journal of Cleaner Production 2013, 50, 1-11.

[7] Muianga, C.; Rice, C.; Lentz, T.; Lockey, J.; Niemier, R.; Succop, P. Checklist model to improve work practices in small-scale demolition operations with silica dust exposures. International Journal of Environmental Research and Public Health 2012, 9, 343-361.

[8] Hudgins, H. T. Demolition of concrete structures. Concrete Construction 1987, 32(1), Aberdeens Group, Addison, III., 24-31.

[9] Safe Work Australia. Work-related injuries resulting in hospitalization July 2006 to June 2009 2013, pp. 22.

[10] Zaharuddin, W.; Paraskevas, I.; Liu, C. Accident avoidance importance for building demolition. In CIB W099 2009: Working together: planning, designing and building a healthy and safe construction industry, CIB W099 Working Commission on Construction Safety and Health, Melbourne, Australia, 21-23 Oct. 2009; Lingard, H.; Cooke, T.; Turner, M.; RMIT University: Melbourne, Vic, Australia 2009; pp. 9-14.

[11] Gürcanl1, G. E.; Müngen, U. Analysis of construction accidents in Turkey and responsible parties. Industrial Health 2013, 51(6), 581-595. 
[12] Gürcanlı, G. E. A Risk Analysis Method for Occupational Safety in Construction Sites Using Fuzzy Sets. PhD Thesis, İstanbul Technical University, İstanbul, Turkey, January 2006.

[13] Plan Ahead for Demolition Site Safety. Available online: http: //www.forconstructionpros.com/article/10304530/plan-aheadfor-demolition-site-safety (accessed on 4 November 2015).

[14] Recent Fatalities Serve as a Reminder to Protect Workers from https:/www.osha.gov/pls/oshaweb/owadisp.show_document? p_table=NEWS_RELEASES\&p_id=26331 (accessed on 4 November 2015).

[15] NIOSH. NIOSH Special Hazard Review Identifying High-Risk Small Business Industries; U.S. Department of Health and Human Services Public Health Service \& Centers for Disease Control and Prevention National Institute for Occupational Safety and Health.: Cincinnati, USA, 1999.

[16] WorkSafeBC. Mechanisms of Injury Demolition 2014, pp. $1-4$.

[17] State of the Demolition Industry. Available online: http://ww w.cdworldmag.com/index.php/features/730-state-of-the-demo lition-industry-1 (accessed on 4 November 2015).

[18] Safe Work Australia. Code of Practice Demolition Work 2011, pp. 5.

[19] New Zealand Demolition and Asbestos Association (NZDAA). Demolition - Best Practice

[20] Guidelines for Demolition in New Zealand. Available online: www.business.govt.nz/worksafe/information-guidance/all-gui dance-items/best-practice-guidelines-for-demolition-in-new-z ealand (accessed on 10 July 2015).

[21] Building Department Hong Kong. Code of Practice for Demolition of Buildings 2004, pp. 2.

[22] OSHA, USA. 29 CFR Part 1926, Subpart T - Demolition. Availab37 o www.osha.gov/pls/oshaweb/owadisp.show_document?p_tabl $\mathrm{e}=$ STANDARDS\&p_id=10942 (accessed on 10 July 2015).

[23] Anumba, C.; Marino, B.; Gottfried, A.; Egbu, C. Research project: Health and safety in refurbishment involving demolition and structural instability, 1st ed.; Health and Safety Executive: Sudbury, UK, 2004, pp. 3-4.

[24] Taraf. Available online: www.taraf.com.tr/yasam/kentsel-donusumde-kanser-tehlikesi/ (accessed on 07 July 2015).

[25] ILO, C162 - Asbestos Convention, 1986 (No. 162) Available on http://www.ilo.org/dyn/normlex/en/f?p=NORMLEXPUB:121 00:0::NO::P12100 INSTRUMENT ID:312307 (accessed on 4 November 2015).

[26] ILO, R172 - Asbestos Recommendation, 1986 (No. 172) Available online http://www.ilo.org/dyn/normlex/en/f?p=1000:12100:0::NO:1 2100:P12100_INSTRUMENT_ID:312510 (accessed on 4 November 2015).

[27] WHO. Elimination of asbestos-related diseases: Exposure to asbestos and its impacts on public health are substantial; World Health Organization: Geneva, Switzerland, 2006.

[28] Akboğa, Ö.; Baradan, S. Asbestin inşaat sektöründeki yeri ve maruziyetin önlenmesi. Türkiye Mühendislik Haberleri 2011, 469, 69-77.
[29] H SE, Demolition Available online: http://www.hse.gov.uk/co nstruction/safetytopics/demolition.htm (accessed on 4 November 2015).

[30] ILO, International Labor Standards on Occupational Safety and Health Available online:http://www.ilo.org/global/standar ds/subjects-covered-by-international-labour-standards/occupat ional-safety-and-health/lang--en/index.htm (accessed on 4 November 2015)

[31] Safe Work Australia, Construction Statistics Available online: http://www.safeworkaustralia.gov.au/sites/swa/statistics/indus try/construction/pages/construction (accessed on 4 November 2015).

[32] OSHA, Demolition: Construction in Reverse, with Additional Hazards Available online:

https://www.osha.gov/doc/topics/demolition/ (accessed on 4 November 2015).

[33] Li, R. Y. M.; Poon, W. Why Do Accidents Happen, A Critical Review on the Evolution of the Construction Accident Causation Models. Construction Safety 2013, DOI: 10.1007/978-3-642-35046-7_2,

[34] Anumba, C.; Marino, B.; Gottfried, A.; and Egbu C. Health and safety in refurbishment involving demolition and structural instability, Prepared by Loughborough University and Milan Polytechnic for the Health and Safety Executive, 2004, ISBN 0717628205.

[35] Fabiano, B.; Curro, F.; Reverberi, A.P.; Pastorino, R.A. statistical study on temporary work and occupational accidents: Specific risk factors and risk management strategies, Safety Science 2008, Vol.46, pp. 535-544.

[36] Hosseinian S.; Torghabeh Z. J. Major Theories of Construction Accident Causation Models: A Literature Review, International Journal of Advances in Engineering \& Technology 2012, 4:53-66.

37 on Ripgdahl L. H. Relationships between Accident Investigations, Risk Analysis, and Safety Management, Journal of Hazardous Materials 2004, 111:13-19.

[38] Quarmby, T. R. Safe, Healthy And Sustainable Demolition. PhD Thesis, Loughborough University, Loughborough, England, July 2011.

[39] Abdullah, D. N. M. A; Wern, G. C. M. An Analysis of Accidents Statistics in Malaysian Construction Sector. In International Conference on E-business, Management and Economics, Hong Kong, 2010.

[40] A Buckler (Haulage). Construction Phase Plan (Demolition)

ine: 2011, pp. 75-114.

[41] Bin Abas, N. R. Risk Assessment for Demolition Works in Malaysia. MSc Thesis, Universiti Malaysia Pahang, Malaysia, 2010.

[42] OSHA, Fatality and Catastrophe Investigation Summaries Available online:

https://www.osha.gov/pls/imis/accidentsearch.html (accessed on 5 November 2015).

[43] ILO. Report of the conference, Sixteenth International Conference of Labor Statisticians, 6-15 Oct. 1998; International Labor Office: Geneva, Switzerland, 1998.

[44] Seixas, N.; Sanders, J.; Sheppard, L.; Yost, M.G. Exposure assessment for acute injuries on construction sites: 
Conceptual development and pilot test. Applied Occupational and Environmental Hygiene 1998, 13(5), 304-312.

[45] Karabay, M.; Uluslararası İnşaat Sektöründe Politik Risk ve Fuzzy Analiz Yöntemi. PhD Thesis, İstanbul Technical University, İstanbul, Turkey, 1997.

[46] Morote, A.N.; Vila, F.R. A fuzzy approach to construction project risk assessment. International Journal of Project Management 2011, 29, 220-231.

[47] Mure, S.; Demichela, M. Fuzzy application procedure (FAP) for the risk assessment of occupational accidents. Journal of Loss Prevention in the Process Industries 2009, 22, 593-599.

[48] Bell, P.M.; Badiru, A.B. Fuzzy modelling and analytic hierarchy processing to quantify risk levels associated with occupational injuries Part I. IEEE Transactions on Fuzzy Systems 1996, 4(2), 124-131.

[49] Dağdeviren, M.; Yüksel, İ. Developing a fuzzy analytic hierarchy process (AHP) model for behavior-based safety management. Information Sciences 2008, 178, 1717-1733.

[50] Ale, B.J.M.; Baksteen, H.; Bellamy, L.J.; Bloemhof, A.; Goossens, L.; Hale, A.; Mud, M.L.; Oh, J.I.H.; Papazoglou, I.A.; Post, J.; Whiston, J.Y. Quantifying occupational risk: The development of an occupational risk model. Safety
Science 2008, 46(2), 176-185.

[51] Pinto, A.; Nunes, I.L.; Ribeiro, R.A. Occupational risk assessment in construction industry - Overview and reflection. Safety Science 2011, 49, 616-624.

[52] Northern Safety. Construction phase plan (Demolition) 2011, pp. 74-113.

[53] OSHA, Commonly Used Statistics Available online: https://www.osha.gov/oshstats/commonstats.html (accessed on 10 November 2015).

[54] Abdelhamid, T.S.; Everett, J.G. Identifying root causes of construction accidents. Journal of Construction Engineering and Management 2000, 126(1), 52-60.OSHA. Introduction to OSH 2012, pp. 1-39.

[55] Bhandari, M.G.; Kulkarni V.K.; Malviya R.K. Building demolition: ground to earth important as construction. International Journal of Emerging Technology and Advanced Engineering 2013, 3(4), 396-401.

[56] Dust Boss, Safety and health training for demolition and reconstruction activities Available online: http://www.dustboss.com/support/dust-related-health-safety-is sues/safety-and-health-training/ (accessed on 17 November 2015). 